Portland State University

PDXScholar

\title{
Development, Deployment, and Assessment of a New Educational Paradigm for Transportation Professionals and University Students
}

Christopher M. Monsere

Portland State University, monsere@pdx.edu

Follow this and additional works at: https://pdxscholar.library.pdx.edu/trec_reports

Part of the Transportation Commons, Transportation Engineering Commons, and the Urban Studies Commons

Let us know how access to this document benefits you.

\section{Recommended Citation}

Monsere, Christopher. Development, Deployment, and Assessment of a New Educational Paradigm for Transportation Professionals and University Students. OTREC-ED-12-03. Portland, OR: Transportation Research and Education Center (TREC), 2013. https://doi.org/10.15760/trec.80

This Report is brought to you for free and open access. It has been accepted for inclusion in TREC Final Reports by an authorized administrator of PDXScholar. Please contact us if we can make this document more accessible: pdxscholar@pdx.edu. 


\section{5) OTREC}

EDUCATION

PROJECT SUMMARY REPORT

\title{
Development, Deployment, and Assessment of a New Educational Paradigm for Transportation Professionals and University Students
}

\author{
OTREC-ED-12-03
}

April 2013

Additional information about this project, including associated project deliverables, can be found at http://otrec.us/project/298 



\section{ABOUT THIS PROJECT SUMMARY REPORT}

The purpose of an OTREC Education project is to immediately enhance educational opportunities for OTREC graduate and undergraduate students, and subsequently for students at universities throughout the United States as the results of the project are disseminated.

In most cases, the result of an Education project is a new course or module, including curriculum materials, lesson plans and related resources. The purpose of this project summary report is to document the project's methodology and outcomes. The deliverables may be included directly or by reference, but will always be readily available on the project's webpage at http://otrec.us.

We expect that this report will be primarily of value to researchers who may be considering a project to replicate or adapt, or who want to apply the lessons learned through the way this report was conducted rather than use its results. We encourage you to contact the principal investigator or OTREC staff for further information.

\section{ACKNOWLEDGEMENTS}

This project was funded by the Oregon Transportation Research and Education Consortium (OTREC) and the Federal Highway Administration (FHWA).

\section{DISCLAIMER}

The contents of this report reflect the views of the authors, who are responsible for the facts and the accuracy of the information presented herein. This document is disseminated under the sponsorship of the U.S. Department of Transportation's University Transportation Centers Program, in the interest of information exchange. The U.S. Government assumes no liability for the contents or use thereof. 



\title{
DEVELOPMENT, DEPLOYMENT AND ASSESSMENT OF A NEW EDUCATIONAL PARADIGM FOR TRANSPORTATION PROFESSIONALS AND UNIVERSITY STUDENTS
}

\section{PROJECT SUMMARY REPORT}

\author{
OTREC Project No. 2010-298 \\ Principal Investigator: Christopher Monsere \\ University Affiliation: Portland State University \\ Project Website: http://otrec.us/project/298
}

\section{INTRODUCTION}

This project summary report describes the execution of OTREC Project \#298 (Development, Deployment and Assessment of a New Educational Paradigm for Transportation Professionals and University Students). The project is one facet of a multiyear collaboration of the Region X Transportation Consortium that was sponsored by the Federal Highway Administration (FHWA). The regional collaboration aims to shift the traditional paradigm of engineering course delivery to foster a more hands-on approach.

The University of Idaho, for example, has created activity-based modules for a traffic signals course, while the University of Washington developed similar modules for a freight systems course. The focus of the work undertaken at Portland State University (PSU) is aimed at introducing transportation engineering graduate students to methods for evaluating and analyzing transportation data.

\section{BACKGROUND}

Traditionally, engineering coursework has been delivered in a lecture-based format with accompanying exercises assigned for time outside of class. The activity-based approach to learning aims to keep students engaged in and responsible for their own learning processes. This approach has been shown to be more effective than conventional teaching approaches in terms of long-term retention of the educational material (National Research Council, 2003; Beyerlin, Holmes and Apple, 2007; Wiggins and McTighe, 2005).

\section{PROJECT DESCRIPTION}

PSU's involvement in the FHWA initiative began in the summer of 2009. Professors Monsere and Figliozzi traveled to the University of Idaho (UI) on Aug. 6-7, 2009, to participate in a twoday workshop on course design methods. Together with the UI team, the PSU faculty produced a draft course design document. In November 2009, Monsere and Haire attended a two-day 
workshop at the UI with the other project researchers. The UI serves as the lead institution on the larger FHWA project and has spent more time in the past focusing on activity-based pedagogy. As part of an earlier project, the UI team had developed more than 100 detailed activities focused on traffic signal systems. As part of the UI workshop, project team members were introduced to these signal systems activities in the university's transportation computer lab. By pairing the researchers into teams and walking them through the same exercises the students used in the class, it became much clearer how to develop appropriate activities.

This lab-based experience proved vital to the researchers' understanding of the types and design of activities desired through the goals of the project. In addition to exposing the researchers to the appropriate design of activities, the UI team members made astute observations about the interactions between team pairs and the learning process undertaken by each pair.

On returning to Portland, the PSU team pursued the project goals with greater direction. Monsere and Haire discarded the activities they had used in 2009-10 because of weaknesses they recognized as a result of the June 2010 workshop. Over the following months, Monsere augmented the Introduction to Transportation Engineering Research Methods curriculum with detailed activity-based learning modules, which were delivered in the class and more closely resembled the example activities used in the workshop.

The new activities lead transportation engineering graduate students through the practical process of evaluating and analyzing transportation data using a variety of software packages. Beginning with Microsoft Excel, with which it was assumed the students had a working knowledge, increasingly large datasets from PSU's PORTAL database were explored and examined. From Excel, the students grew to use SQL and R in investigating transportation data, which included freeway traffic data from the Oregon Department of Transportation (ODOT) loop detector network; weigh-in-motion data from ODOT; bicycle data; and transit bus data (automatic vehicle location (AVL) and automatic passenger counter (APC) data) from TriMet, the regional public transportation provider. Activities built sequentially, using skills or the results of previous activities to lead into subsequent phases of the course.

Most class sessions occurred in the computer lab and included one or two activities per class, some of which were continued outside of class as homework. Some activities were intended for time outside of class, such as readings or extra effort required on activities begun in class. Although most activities were designed for students to work individually, some students had greater experiences working with the coding and computer-based logic required in many activities, and therefore the computer lab setting proved beneficial in that these students could assist their peers as needed. A few class sessions included brief lectures from the instructor (Monsere) when needed to provide context to the day's activities. A sample of a typical activity (written by Monsere) from the course can be found in the appendix of this report.

At the end of the course, students chose from one of six problem statements and sought to use the skills they had developed in the class to answer a targeted question from the appropriate dataset, with which the students had built familiarity in previous activities. 


\section{PROJECT OUTCOMES}

Consistent with the methodology of FHWA's larger initiative, Monsere documented lessons learned from the Fall 2010 offering of Introduction to Transportation Engineering Research Methods into the website http://www.transportation-data.com/ which includes products from all of the activities associated with the FHWA initiative.

FHWA's objective is for new activity-based courses and modules to be adopted by other universities and professional training organizations. Additionally, the FHWA initiative includes a testing phase for all new learning activities to demonstrate their superior educational outcomes. Meanwhile, FHWA continues to pursue activity-based course development within the region.

\section{REFERENCES}

National Research Council, 2003. Evaluating and Improving Undergraduate Teaching in Science, Technology, Engineering, and Mathematics.

Beyerlin, Steven, C. Holmes and D. Apple, 2007. Faculty Guidebook.

Wiggins, Grant and J. McTighe, 2005. Understanding by Design, Expanded $2^{\text {nd }}$ Edition.

\section{ONLINE RESOURCES}

OTREC's project webpage (http://otrec.us/project/298) includes a sample activity from the researchers work and the activity program workbook.

The Region X Transportation Consortium's project webpage (http://transportationeducation.wordpress.com) includes a final report and links to information from each university's project. 
